\title{
MDM4 Gene Amplification
}

National Cancer Institute

\section{Source}

National Cancer Institute. MDM4 Gene Amplification. NCI Thesaurus. Code C156763.

A molecular genetic abnormality indicating the presence of multiple copies of the MDM4 gene. 